\title{
FUNCTIONAL ACTION BIOLOGICAL IMAGE DATA SCREENING METHOD TO REDUCE SPORTS INJURY
}

\author{
MÉTODO DE TRIAGEM DEDADOS BIOLÓGICOS DEAÇÃO FUNCIONAL PARA REDUZIRLESÕESESPORTIVAS
}

MÉTODO DE SELECCIÓNDEDATOS DE IMÁGENES BIOLÓGICAS DEACCIÓN FUNCIONAL PARA REDUCIR LAS

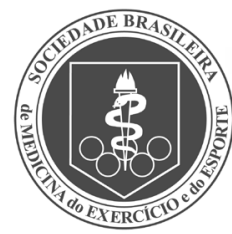

Original Article ARTIGO ORIGINAL Artículo Original LESIONES DEPORTIVAS

Youdong Wang ${ }^{1}$ (D)

(Physical Education Professional)

1. Dalian Ocean University,

Dalian,China.

\section{Correspondence:}

Dalian Ocean University, Dalian, China.wangyoudong29@126.com

\begin{abstract}
Introduction: The Functional Movement Test (FMS) is an evaluation method for the basic movement patterns of the human body that is designed by Gray Cook. Objective: This paper explores the application value of functional action test (FMS) biological image data in the risk assessment of sports injuries of Chinese rugby players. Methods: Taking the active national football team and provincial football players as the object, the standard FMS test is used to collect the data to determine the best deadline for the total FMS score. Results: The area under the ROC curve (AUC) of the overall athletes, men and women was significantly different from the assumption of $A \cup C=0.5$, which were $0.780(P=0.000), 0.877(P=0.001), 0.7130(P=0.013)$; The best cutoff points corresponding to the total score of FMS are 13.5 points, 15.5 points, and 13.5 points, respectively. The chi-square test showed that the prevalence of the positive group (the total FMS score was less than the corresponding cutoff point) was significantly higher than the negative group (the total FMS score was greater than the corresponding cutoff point) $(P<0.01)$. The OR values of the total athlete, male and female FMS total score positive groups were 25.85 (95\%Cl: 3.34 200.23), 25.00 (95\%Cl: 2.36 264.80), 14.22 (95\%Cl: 1.76 114.92). Conclusions: Among Chinese rugby players, the total score of FMS has a strong correlation with non-contact sports injuries. The score is 13.5 for women and 15.5 for men. Level of evidence Il; Therapeutic studies - investigation of treatment results.
\end{abstract}

Keywords: Functional action; Biological image data; Triage.

\section{RESUMO}

Introdução: O Teste de Movimento Funcional (FMS) é um método de avaliação dos padrões básicos de movimento do corpo humano, projetado por Gray Cook. Objetivo: Este artigo explora o valor da aplicação de dados de imagem biológica do teste de ação funcional (FMS) na avaliação do risco de lesões esportivas em jogadores de rúgbi chineses. Métodos: visando a seleção nacional de futebol e jogadores de futebol da província, o teste FMS padrão foi usado para coletar os dados e determinar o melhor limite para o escore total do FMS. Resultados: A área sob a curva ROC (AUC) dos atletas em geral, homens e mulheres, foi significativamente diferente da suposição de AUC =0,5, que foi $0,780(P=0,000), 0,877(P=0,001), 0,7130(P=0,013)$; Os melhores pontos de corte para o escore total da FMS são 13,5 pontos, 15,5 pontos e 13,5 pontos, respectivamente. O teste do qui-quadrado mostrou que a prevalência do grupo positivo (a pontuação total da FMS foi menor do que o ponto de corte correspondente) foi significativamente maior do que a do grupo negativo (a pontuação total da FMS foi maior do que o ponto de corte correspondente) ( $P$ $<0,01)$. Os valores de OR do total de atletas, homens e mulheres, grupos positivos de pontuação total de FMS foram 25,85 (IC 95\%: 3,34 200,23), 25,00 (IC 95\%: 2,36 264,80), 14,22 (IC 95\%: 1,76 114,92). Conclusões: Entre os jogadores de rúgbi chineses, a pontuação total da FMS tem uma forte correlação com lesões esportivas sem contato. A pontuação é de 13,5 para mulheres e 15,5 para homens. Nível de evidência ll; Estudos terapêuticos-investigação dos resultados do tratamento.

Descritores: Ação funcional; Dados de imagem biológica; Triagem.

\section{RESUMEN}

Introducción: La prueba de movimiento funcional (FMS) es un método de evaluación de los patrones de movimiento básicos del cuerpo humano diseñado por Gray Cook. Objetivo: Este artículo explora el valor de la aplicación de los datos de imágenes biológicas de la prueba de acción funcional (FMS) en la evaluación del riesgo de lesiones deportivas de los jugadores de rugby chinos. Métodos: Tomando como objeto el equipo nacional de fútbol y los jugadores de fútbol provinciales, se utilizó la prueba estándar de FMS para recopilar los datos y determinar el mejor límite para la puntuación total de FMS. Resultados: El área bajo la curva ROC (AUC) de los atletas en general, hombres y mujeres fue significativamente diferente del supuesto de $A \cup C=0.5$, que fue $0.780(P=0.000), 0.877$ ( $P$ $=0.001), 0.7130(P=0,013)$; Los mejores puntos de corte correspondientes a la puntuación total de FMS son 13,5 puntos, 15,5 puntos y 13,5 puntos, respectivamente. La prueba de chi-cuadrado mostró que la prevalencia del grupo positivo (la puntuación total de FMS fue menor que el punto de corte correspondiente) fue significativamente más alta que la del grupo negativo (la puntuación total de FMS fue mayor que el punto de corte correspondiente) $(P<0.01$ ). Los valores de OR del total de atletas, hombres y mujeres, grupos positivos de puntuación total de FMS 
fueron 25,85 (95\% Cl:3,34 200,23), 25,00 (95\% Cl:2,36 264,80), 14,22 (95\% Cl: 1,76 114,92). Conclusiones: Entre los jugadores de rugby chinos, la puntuación total de FMS tiene una fuerte correlación con las lesiones de deportes sin contacto. La puntuación es de 13,5 para las mujeres y 15,5 para los hombres. Nivel de evidencia ll; Estudios terapéuticos-investigación de los resultados del tratamiento.

Descriptores: Acción funcional; Datos de imágenes biológicas; Triaje.

\section{INTRODUCTION}

The Functional Movement Test (FMS) is an evaluation method for the basic movement patterns of the human body that is designed by Gray Cook and other obstacles or defects. My country's competitive sports industry has begun to apply FMS and gradually promote it, but it has not yet established a large database of related FMS. In this study, the Chinese rugby players were used as the subjects to establish the injury and FMS database, and the receiver operating characteristics (ROC) curve was used to formulate the FMS risk assessment criteria, and the risk of non-contact injury was evaluated, with a view to the FMS in China's rugby. The application of athletes provides a scientific basis. ${ }^{1}$

\section{METHODS}

Take the national team, the province, the city team active player as the investigation object, uses the questionnaire, the physical examination and so on method to follow up the investigation and the record.

\section{Exercise test}

The FMS has 7 tests (squat, hurdle, straight lunge, shoulder flexibility, active straight knee lift, torso stable push-up, rotation stability), 3 exclusion tests (shoulder impact test, spine extension) Test, spinal flexion test), each test score is $0 \sim 3$ points, the total score is $0 \sim 21$ points. ${ }^{2}$

\section{Image acquisition}

The American company GE's SignaHDxt1.5T magnetic resonance scanner was used.

\section{Statistics}

The sensitivity matrix of the biological image sensitive field is calculated according to formula (1).

$$
\boldsymbol{S}_{\ddot{j}}(k)=\mu(k) \cdot \frac{\boldsymbol{C}_{j}^{m}(k)-\boldsymbol{C}_{j}^{l}}{\boldsymbol{C}_{j}^{h}-\boldsymbol{C}_{j}^{l}} \cdot \frac{1}{\varepsilon_{h}-\varepsilon_{l}}
$$

In the formula, $\mu(k)$ is the coefficient determined by the area of pixel $k$, and is defined as the ratio of the total area to the area of the pixel. $C_{i j}^{l}, C_{i, j}^{h}$, respectively, are the biological images when the tube is filled with a Low dielectric constant phase and a high dielectric constant phase, and $C_{i j}$ is the tube. The measured biological image of the ij image pair when filled with a two-phase mixed medium. The biological image is calculated according to formula (2):

$C_{i, j}=\frac{Q}{\phi_{i}-\phi_{j}}=\frac{\oint_{A} \varepsilon(x, y) \boldsymbol{A} \mathrm{d} \boldsymbol{A}}{\phi_{i}-\phi_{j}}=-\frac{\oint_{A} \varepsilon(x, y) \nabla \phi(x, y) \mathrm{d} \boldsymbol{A}}{\phi_{i}-\phi_{j}}$

Among them, $\phi_{i}-\phi_{j}$ is the potential difference between the excitation image $i$ and the measurement image $j, A$ is the closed curved surface surrounding the image $j$, and $Q$ is the sensing image on the image j. After obtaining the sensitivity matrix, the discrete form of formula (2) after local linearization can be expressed as:

$$
\ddot{\boldsymbol{e}}_{M \times 1}=\boldsymbol{S}_{M \times N} \boldsymbol{G}_{N \times 1}
$$

In the formula, $\ddot{\boldsymbol{e}}$ is the normalized biological image vector, $\mathrm{G}$ is the normalized image grayscale matrix, $\mathrm{S}$ is the sensitivity matrix, and its definition is shown in equation (1), $M$ is the independent measurement number of the ECT system, $N$ is the number of elements of the mesh in the field.

To improve imaging quality, the sensitivity matrix is usually normalized, as shown in equation (4):

$$
\mathbf{S}_{i, j}^{*}=\frac{\mathbf{S}_{i, j}}{\sum_{k=1}^{M} \mathbf{S}_{i, j}}
$$

Normalization must satisfy:

$$
\begin{aligned}
& \lambda=f\left(C_{m}, C_{h}, C_{l}\right) \\
& f\left(C_{l}, C_{h}, C_{l}\right)=0 \\
& f\left(C_{h}, C_{h}, C_{l}\right)=1
\end{aligned}
$$

\section{RESULTS}

\section{The general situation of the subjects}

The subjects came from my country's active national rugby training team, provincial and municipal rugby teams, and a total of 118 rugby players, including 28 males and 90 females. ${ }^{3}$ The general situation of the subjects is shown in Table 1.

\section{Overall non-contact damage}

After excluding 12 simple contact injury athletes, 81 non-contact injury athletes (prevalence rate 76.4\%), including 14 male athletes (prevalence rate $56 \%$ ) and 67 female athletes (prevalence rate $82.7 \%$ ). There was a significant difference in the prevalence of non-contact injury between men and women ( $P=0.006)$.

\section{FMS test score}

As shown in Table 3, the average score of the athletes' overall FMS test is 14.3, male athletes are 15.1, female athletes are 14.0, and there is no significant difference between men and women ( $P>0.05)$. The overall average squat score of athletes is 2.1, male athletes are 2.5, female athletes are 2.0, male athletes are significantly higher than female athletes

Table 1. Basic situation of rugby players.

\begin{tabular}{c|c|c|c|c}
\hline & Number of people & age) & Height $(\mathbf{c m})$ & Weight $(\mathbf{k g})$ \\
\hline male & 28 & $21.1 \pm 2.9$ & $183.5 \pm 5.2$ & $85.1 \pm 8.5$ \\
\hline Female & 90 & $20.2 \pm 2.8$ & $171.1 \pm 5.7$ & $65.7 \pm 6.5$ \\
\hline overall & 118 & $20.4 \pm 2.8$ & $174.0 \pm 7.6$ & $70.3 \pm 10.8$ \\
\hline
\end{tabular}


$(P<0.01)$; hurdle step, straight lunge, shoulder flexibility, active straight knee lift, There is no significant difference between male and female in the six tests of trunk stability push-ups and rotation stability $(P>0.05) .{ }^{4}$

In the FMS exclusion test or 7 tests, pain was positive and no pain was negative. As shown in Table 4, the overall athletes accounted for $55.6 \%$ positive and $44.4 \%$ negative. There was no statistically significant difference between male and female athletes ( $P>0.05)$.

The overall asymmetry of athletes accounted for $60.2 \%$ (71), and symmetry accounted for $39.8 \%$ (47). There was no statistically significant difference between male and female athletes $(P>0.05)$.

\section{FMS total score}

As shown in Table 6 and Figure 1, the area under the ROC curve (AUC) of the overall athlete, male and female athletes is significantly different from the assumption of $A \cup C=0.5$, respectively $0.780(P=0.000)$, 0.877 ( $P=0.001), 0.7130$ ( $P=0.013)$. The ROC curve chart analyzes the sensitivity and 1-specificity and 1-denden index of non-contact injury judged by different cutoff points in Table 7. The largest Yoden indexes of the athletes, men and women are $0.479,0.623$ and 0.478 respectively, and the best cutoff points corresponding to the total score of FMS are $13.5,15.5$ and 13.5 .

The athletes were divided into negative groups (FMS total score: overall>13.5; male>15.5; male>13.5) according to the best cutoff point of overall athlete, male and female FMS total scores, and positive group

Table 2. Non-contact injuries of rugby players.

\begin{tabular}{c|c|c|c}
\hline & Number of injuries & No injuries & Prevalence \\
\hline male & 14 & 11 & $56 \%$ \\
\hline Female & 67 & 14 & $82.7 \%$ \\
\hline overall & 81 & 25 & $76.4 \%$ \\
\hline
\end{tabular}

Table 3. Football Player FMS Test Score.

\begin{tabular}{|c|c|c|c|c|}
\hline & overall & $\begin{array}{c}\text { Male } \\
(n=25)\end{array}$ & $\begin{array}{c}\text { Female } \\
(n=81)\end{array}$ & $\begin{array}{l}\text { Comparison of } P \\
\text { value between } \\
\text { men and women }\end{array}$ \\
\hline Squat & $2.1 \pm 0.7$ & $2.5 \pm 0.6$ & $2.0 \pm 0.7$ & 0.004 \\
\hline Hurdle & $2.0 \pm 0.5$ & $2.2 \pm 0.5$ & $2.0 \pm 0.5$ & 0.098 \\
\hline Straight lunge & $2.3 \pm 0.7$ & $2.3 \pm 05$ & $2.3 \pm 0.7$ & 0.657 \\
\hline Shoulder flexibility & $1.8 \pm 1.3$ & $1.7 \pm 1.2$ & $1.9 \pm 1.3$ & 0.563 \\
\hline Active straight knee lift & $2.7 \pm 0.5$ & $2.7 \pm 0.5$ & $2.7 \pm 0.5$ & 0.887 \\
\hline Torso stability push-ups & $1.7 \pm 1.2$ & $2.0 \pm 1.2$ & $1.5 \pm 1.2$ & 0.058 \\
\hline Rotational stability & $1.6 \pm 0.9$ & $1.7 \pm 0.9$ & $1.6 \pm 0.9$ & 0.672 \\
\hline FMS total score & $14.3 \pm 3.0$ & $15.1 \pm 2.7$ & $14.0 \pm 3.0$ & 0.095 \\
\hline
\end{tabular}

FMS elimination test and test pain.

Table 4. Rugby players FMS exclusion test.

\begin{tabular}{c|c|c|c|c}
\hline \multirow{2}{*}{} & \multicolumn{2}{|c|}{ Rule out positive test } & \multicolumn{2}{c}{ Negative test } \\
\cline { 2 - 5 } & $\begin{array}{c}\text { Number of } \\
\text { people }\end{array}$ & proportion & $\begin{array}{c}\text { Number of } \\
\text { people }\end{array}$ & proportion \\
\hline male & 15 & $53.60 \%$ & 13 & $46.40 \%$ \\
\hline Female & 50 & $56.20 \%$ & 39 & $43.80 \%$ \\
\hline overall & 65 & $55.60 \%$ & 52 & $44.40 \%$ \\
\hline
\end{tabular}

FMS asymmetry on the left and right sides.

Table 5. Asymmetry of FMS on the left and right sides of Chinese football players.

\begin{tabular}{c|c|c|c|c}
\hline \multirow{2}{*}{} & \multicolumn{2}{|c|}{ Asymmetry } & \multicolumn{2}{c}{ symmetry } \\
\cline { 2 - 5 } & $\begin{array}{c}\text { Number of } \\
\text { people }\end{array}$ & proportion & $\begin{array}{c}\text { Number of } \\
\text { people }\end{array}$ & proportion \\
\hline male & 18 & $64.30 \%$ & 10 & $35.70 \%$ \\
\hline Female & 53 & $58.90 \%$ & 37 & $41.10 \%$ \\
\hline overall & 71 & $60.20 \%$ & 47 & $39.80 \%$ \\
\hline
\end{tabular}

FMS testing and damage risk.
Table 6. AUC calculation results of the ROC curve of the total score of the athletes, men, and women FMS.

\begin{tabular}{c|c|c|c|c}
\hline \multirow{2}{*}{ AUC } & \multirow{2}{*}{ P value } & Asymptotic 95\% & $\begin{array}{c}\text { Confidence } \\
\text { interval (95\%Cl) }\end{array}$ \\
\cline { 4 - 5 } & & & Lower limit & Upper limit \\
\hline male & 0.877 & 0.001 & 0.744 & 1 \\
\hline Female & 0.713 & 0.013 & 0.595 & 0.83 \\
\hline overall & 0.78 & 0 & 0.69 & 0.869 \\
\hline
\end{tabular}

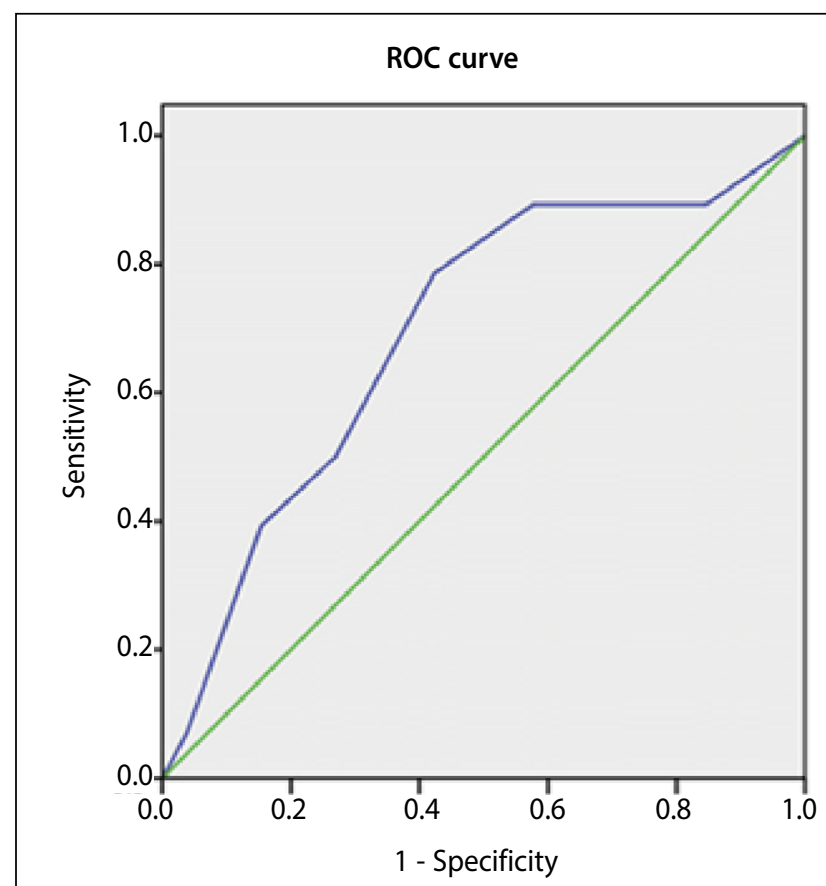

\section{Coordinates of the curve}

Test result variable(s): FMS

\begin{tabular}{|c|c|c|}
\hline FMS score & Sensitivity & 1 - Specificity \\
\hline 11.000 & 1.000 & 1.000 \\
12.5000 & .893 & .846 \\
\hline 13.5000 & .893 & .577 \\
14.5000 & .786 & .423 \\
\hline 15.5000 & .500 & .269 \\
16.5000 & .393 & .154 \\
17.5000 & .179 & .077 \\
18.5000 & .071 & .038 \\
20.000 & .000 & .000 \\
\hline
\end{tabular}

Figure 1. ROC curve of total scores of athletes, men, and women FMS.

(total FMS score: overall <13.5; male< 15.5; female <13.5). The chi-square test showed that the prevalence of the positive group was significantly higher than that of the negative group (overall, $P=0.000$; male, $P=0.002$; female, $P=0.002$ ), the OR values of the overall athletes, male and female FMS total scores were respectively 25.85, 25.00, 14.22 .

\section{Damage imaging}

The affected parts of the patients with calf triceps injury are all at the junction of muscle and tendon. There were 18 patients with independent injury of single muscle, accounting for $75 \%$, and 6 patients with combined injury of multiple muscles, accounting for $25 \%$. The cases of independent injury of single muscle were the most common in the medial head of gastrocnemius, accounting for $72.2 \%$ (13/18). Among the cases of combined muscle injury, 5 patients involved 
Table 7. Athletes' total, male and female FMS total score cutoff points to judge the results of non-contact injury.

\begin{tabular}{|c|c|c|c|c|c|c|c|c|c|}
\hline \multirow{2}{*}{$\begin{array}{c}\text { FMS } \\
\text { Total score }\end{array}$} & \multicolumn{4}{|c|}{ Female } & \multicolumn{3}{|c|}{ male } & \multicolumn{2}{|c|}{ overall } \\
\hline & Sensitivity & 1-specificity & Youden Index & Sensitivity & 1-specificity & Youden Index & Sensitivity & 1-specificity & Youden Index \\
\hline & 1.000 & 1.000 & 0.000 & & & & 1.000 & 1.000 & 0.000 \\
\hline 2.0 & 1.000 & 0.985 & 0.015 & & & & 1.000 & 0.988 & 0.012 \\
\hline 5.5 & 1.000 & 0.955 & 0.045 & & & & 1.000 & 0.963 & 0.037 \\
\hline 7.5 & & & & 1.000 & 1.000 & 0.000 & & & \\
\hline 9.5 & 1.000 & 0.881 & 0.119 & 1.000 & 0.857 & 0.143 & 1.000 & 0.877 & 0.123 \\
\hline 11.5 & 1.000 & 0.821 & 0.179 & & & & 1.000 & 0.802 & 0.198 \\
\hline 12.0 & & & & 1.000 & 0.714 & 0.286 & & & \\
\hline 12.5 & 1.000 & 0.657 & 0.343 & & & & 1.000 & 0.667 & 0.333 \\
\hline 13.5 & 0.929 & 0.478 & 0.451 & 1.000 & 0.500 & 0.500 & 0.960 & 0.481 & 0.479 \\
\hline 18.5 & 0.000 & 0.030 & -0.030 & 0.273 & 0.000 & 0.273 & 0.120 & 0.025 & 0.095 \\
\hline 19.5 & 0.000 & 0.015 & -0.015 & & & & 0.000 & 0.012 & -0.012 \\
\hline 20.0 & & & & 0.000 & 0.000 & 0.000 & & & \\
\hline 21.0 & 0.000 & 0.000 & 0.000 & & & & 0.000 & .000 & 0.000 \\
\hline
\end{tabular}

Table 8. Non-contact injuries of the athletes' overall, male, and female FMS total score negative group and positive group.

\begin{tabular}{|c|c|c|c|c|c|c|c|c|c|}
\hline & \multicolumn{3}{|c|}{ Female (cutoff point=13.5) } & \multicolumn{3}{|c|}{ Male (cutoff point = 15.5) } & \multicolumn{3}{|c|}{ Overall (cutoff point $=13.5$ ) } \\
\hline & no damage & damage & Prevalence & no damage & damage & Prevalence & no damage & damage & Prevalence \\
\hline Negative group & 13 & 32 & $71.10 \%$ & 10 & 4 & $28.60 \%$ & 24 & 39 & $61.90 \%$ \\
\hline Positive group & 1 & 35 & $97.20 \%$ & 1 & 10 & $90.90 \%$ & 1 & 42 & $97.70 \%$ \\
\hline$P$ value & \multicolumn{3}{|c|}{0.002} & \multicolumn{3}{|c|}{0.002} & \multicolumn{3}{|c|}{0} \\
\hline OR value & \multicolumn{3}{|c|}{14.22} & \multicolumn{3}{|c|}{25} & \multicolumn{3}{|c|}{25.85} \\
\hline$(95 \% \mathrm{Cl})$ & \multicolumn{3}{|c|}{$1.76 \sim 114.92$} & \multicolumn{3}{|c|}{$2.36 \sim 264.80$} & \multicolumn{3}{|c|}{$3.34 \sim 200.23$} \\
\hline
\end{tabular}

two muscles at the same time, and 1 patient involved three muscles at the same time, including: 2 cases of combined gastrocnemius head injury, 2 cases of combined gastrocnemius muscle head and soleus muscle injury, and medial gastrocnemius muscle injury One case of combined head and soleus muscle injury, and one case of gastrocnemius muscle and lateral head and soleus muscle injury. A total of 31 muscles were injured in 24 patients with calf triceps injury, which were classified according to the degree of injury: 16 in grade I injury, 11 in grade II injury, and 4 in grade III injury; according to injured muscles: 17 medial head of gastrocnemius muscle (54.9\%), 5 lateral heads of gastrocnemius muscle (16.1\%), 9 soleus muscles (29.0\%) (Table 9).

Grade I injury MRI shows that the muscle tendon has a normal shape, and the indirect signs show that there is exudate between the muscle tracts at the injury site, which is a "feather" or "flake" high signal on the T2WI or fat suppression sequence, and other indirect signs such as intermuscular The incidence of effusion and superficial fascia effusion was $22.2 \%$ and $55.7 \%$, respectively. The direct signs of MR of grade II injury are local tearing of the muscle tendon junction, the muscle at the broken end is thinned, and the relaxation of the broken end tendon is slightly "wavy"; the indirect signs of inter-muscular effusion are $72.2 \%$, other indirect signs For example, the incidence of end-of-end effusion, intermuscular effusion and superficial fascia effusion are all 100\%. The direct signs of MR of grade III injury are the complete rupture of the muscle tendon junction, the muscular contraction of the broken end is blunt, and the retraction and thickening of the broken end tendon are "wavy"; the incidence of all indirect signs is $100 \%$ (Figure 2 and 3 ).
Table 9. Injury mode and injury classification of triceps of lower leg (block).

\begin{tabular}{|c|c|c|c|c|c|c|}
\hline \multirow{2}{*}{ Injury site } & \multicolumn{2}{|c|}{ Damage mode } & \multicolumn{3}{|c|}{ degree of damage } & \multirow{2}{*}{$\begin{array}{l}\text { Damag } \\
\text { rate (\%) }\end{array}$} \\
\hline & $\begin{array}{c}\text { Independent } \\
\text { injury }\end{array}$ & $\begin{array}{l}\text { Joint } \\
\text { injury }\end{array}$ & $\begin{array}{l}\text { Grade I } \\
\text { injury }\end{array}$ & $\begin{array}{l}\text { Grade II } \\
\text { injury }\end{array}$ & $\begin{array}{c}\text { Grade III } \\
\text { injury }\end{array}$ & \\
\hline $\begin{array}{c}\text { Gastrocnemius } \\
\text { head }\end{array}$ & 13 & 4 & 3 & 10 & 4 & 54.9 \\
\hline $\begin{array}{l}\text { Gastrocnemius } \\
\text { lateral head }\end{array}$ & 0 & 5 & 5 & 0 & 0 & 16.1 \\
\hline Soleus muscle & 5 & 4 & 8 & 1 & 0 & 29.0 \\
\hline
\end{tabular}
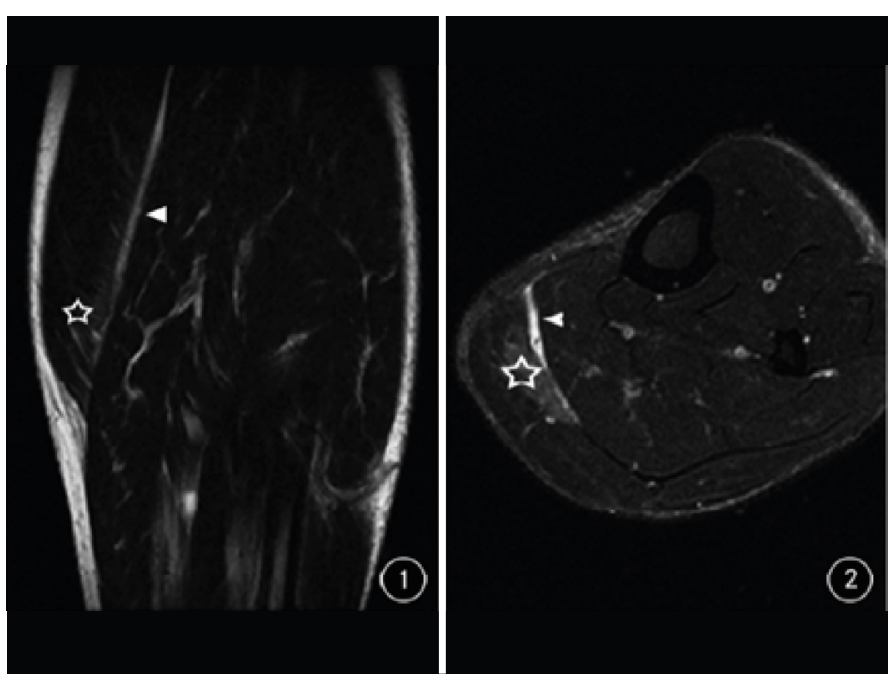

Figure 2. Patients with grade I injury of the medial head of the gastrocnemius muscle 

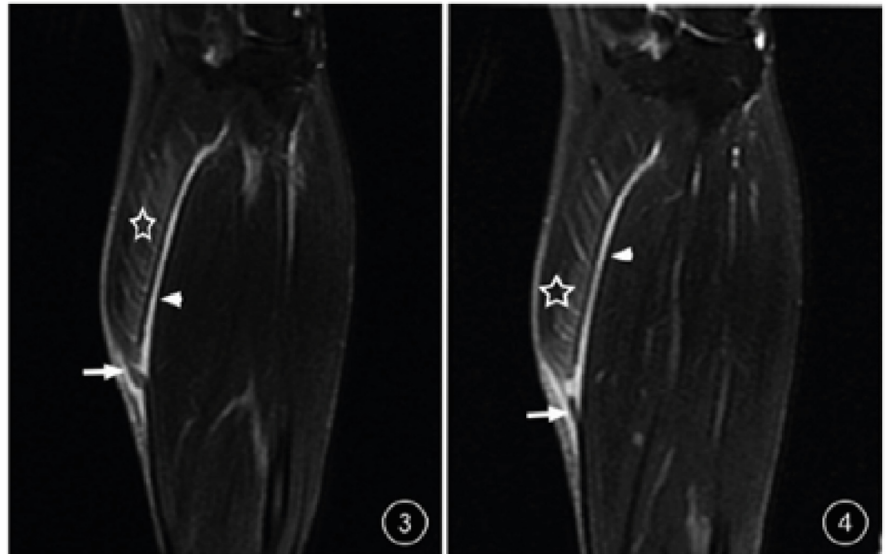

Figure 3. Patients with medial head injury of gastrocnemius muscle.

\section{DISCUSSION}

The AUC value is generally between 1.0 and 0.5 . The closer to 1 , the better the diagnosis effect, but the premise is that the AUC and $A \cup C=0.5$ of the diagnostic test must be Significant difference $(P \leq 0.05)$. AUC has lower diagnostic accuracy when it is 0.5 0.7; AUC has certain diagnostic accuracy when it is 0.7 0.9; AUC has higher diagnostic accuracy when it is above 0.9. Usually the diagnosis value corresponding to the maximum Youden index is the best cutoff point. In this study, the total AUC of our rugby players, male and female, were $0.780(P=0.000), 0.877(P=0.001)$, $0.7130(P=0.013)$, which was significantly different from the assumption of $A \cup C=0.5$, suggesting All have the value of evaluating the risk of non-contact sports injuries, and have a certain diagnostic accuracy. ${ }^{5}$

OR values were $25.85,25.00,14.22$, the results suggest that there is a strong correlation between the total score of FMS and non-contact sports injuries in the Chinese football player population .

\section{CONCLUSION}

In the population of rugby players in China, the total score of FMS has a strong correlation with non-contact sports injuries, and it can be used as an indicator for the risk assessment of non-contact sports injuries. It was 13.5 points, and 15.5 points for men.

The author declare no potential conflict of interest related to this article

AUTHORS' CONTRIBUTIONS: Youdong Wang analyzed and explained that with active national football team and provincial football players as the research objects, the standard FMS test was used to collect data, and the operating characteristics of the receiver were used to track the biological image data (ROC) of the non-contact injury of Chinese rugby players. Curves, odds (OR) and other statistical methods are used to evaluate FMS test-related indicators to assess the value of sports injury risk and determine the best cut-off point for the FMS total score.

\section{REFERENCES}

1. Reddy KS, Srinivasa K. Beating the odds! build theory from emerging markets phenomenon and the emergence of case study research—a"test-tube"typology. Cogent Business \& Management. 2016;2(1):1037225

2. Wu S, Liu J, Liu L. Modeling method of internet public information data mining based on probabilistic topic model. The Journal of Supercomputing. 2019;75(9):5882-97.

3. Committee on Sports-Related Concussions in Youth; Board on Children, Youth, and Families; Institute of Medicine; National Research Council. Sports-Related Concussions in Youth: Improving the Science,
Changing the Culture. Graham R, Rivara FP, Ford MA, Spicer CM, editors. Washington (DC): National Academies Press (US); 2014 Feb 4.

4. Almonroeder TG, Garcia E, Kurt M. The effects of anticipation on the mechanics of the knee during single-leg cutting tasks: a systematic review. Int J Sports Phys Ther. 2015;10(7):918-28.

5. Wu S. Internet public information text data mining and intelligence influence analysis for user intent understanding. Journal of Intelligent \& Fuzzy Systems. 2020;38:487-94. 